\title{
BIOLOGICAL EVALUATION OF BARKI SHEEP UNDER TWO DIFFERENT BREEDING SEASONS
}

\author{
A. M. Ahmed \\ Desert Research Center, Animal Production and Poultry Division, Mataryia, \\ Cairo, Egypt
}

SUMMARY

The present study was conducted to investigate the impact of breeding season on the productivity and profitability of Barki flock. Simulation technique was used based on technical coefficients derived from statistical analysis of the basic data. Basic data utilized in this study were obtained from the accumulated records collected over 34 successive breeding seasons from 1972 to 2005 of Barki sheep flock raised at Maryout Research Station. Biological criteria considered were number of ewes lambed per ewe joined, (EL/EJ), number of lambs born per ewe joined (LB/EJ), number of lambs weaned per ewe joined (LW/EJ), kilogram weaned per ewe joined (KGW/EJ). Deterministic technical coefficients were used to create two simulated flocks of two different breeding seasons. Economical indicators were gross margin (GM) per flock and per ewe, marginal rate of return (MRR), cost of one $\mathrm{kg}$ of meat produced and benefit/cost ratio $(B / C)$. The overall least squares means for $E L / E J$, LB/EJ, LW/EJ and KGW/EJ were $78 \%, 80 \%, 61 \%$ and $11.9 \mathrm{~kg}$, respectively. Analysis of variance showed that autumn breeding season flock was significantly higher than summer breeding season flock in all studied traits. Flock applying autumn breeding season achieved higher gross margin per flock, per ewe, B/C and lower variable cost per one $\mathrm{kg}$ of meat produced than flock applying summer breeding season ( LE 47703 vs. LE 30699), (LE 95.5 vs. LE 61.8), (1.35 vs. 1.25) and (LE 14.6 vs. LE 15.8), respectively. While, MRR was LE 2.40.

Keywords: Barki sheep, biological evaluation, gross margin, simulation

\section{INTRODUCTION}

Fat-tailed sheep are raised in many countries throughout the world, but they are concentrated mainly in subtropical region. They are raised mostly under unfavorable environmental conditions which affect their productivity. The ability of different subtropical sheep breeds to breed throughout the year had been confirmed by many investigators, with variable magnitude ranging from consistent breeding activity all the year round to distinct anoestrous period in summer (El-Fouly et al., 1977, AboulNaga and Aboul-Ela, 1987 and Aboul-Naga et al., 1991). Also, Aboul-Naga (1985) concluded that subtropical breed, of which the fat-tailed constitute a major part, have a prolonged breeding season, and they do not exhibit a clear anoestrous period.

Improvement of lamb production is influenced by the degree of ewe's seasonality. Understanding the seasonality of reproduction is important for developing programs and also important for the planning of breeding seasons to fit with feed resources

Issued by The Egyptian Society of Animal Production 
availability and market requirements. Increasing annual lamb production, is the ultimate goal of sheep producers, since it affects the net return of sheep raising. Lamb production is a function of ewe fertility, prolificacy, mothering ability, lamb mortality and lamb weight. On experimental farms, where all these traits can be measured, a conclusive index of lamb production is the average number of kilograms weaned per ewe joining the ram.

Barki sheep have evolved under semi-arid conditions of North Western Coastal desert of Egypt. Fahmy et al. (1969) showed that Barki sheep are hardy but of low productivity. Improving productivity may be achieved in different ways, which are either a) managerial or b) genetic. Under such circumstances, managerial practices may be thought of as first option for improving lamb production. Few studies are available to evaluate the impact of timing of breeding season on farm profitability. The present study was conducted to investigate the impact of breeding season on the productivity and profitability of the studied flock using simulation technique based on technical coefficients estimated from basic data.

\section{MATERIAL AND METHODS}

\section{Data}

Basic data utilized in this study were obtained from the accumulated records collected over 34 successive breeding seasons from 1972 to 2005 of Barki sheep flock raised under semi-arid conditions at Maryout Research Station, belonging to Desert Research Center. This station is located in the North West of Nile Delta, 180 $\mathrm{km}$ from Cairo.

A total number of 6483 records of Barki ewes representing 2039 breeding ewes were used in the present study. Data of the breeding ewes at each breeding season were recorded as; ewes lambed, lambs born, lambs weaned and litter weight at weaning. Biological performance was expressed as fertility measurement (per ewes exposed to rams).

Biological criteria (technical coefficients) considered were number of ewes lambed per ewe joined (EL/EJ), number of lambs born per ewe joined (LB/EJ), number of lambs weaned per ewe joined (LW/EJ), kilogram weaned per ewe joined $(\mathrm{KGW} / \mathrm{EJ})$. Total weight of lambs weaned was adjusted for 120 days by extrapolation from birth to weaning.

\section{Management Practices}

\section{A. Breeding plan}

Only Barki straight breeding was practiced. The breeding season started in June, since 1972 (summer breeding season), while from 1990 on words ewes were bred in September (autumn breeding season). Breeding ewes were group-mated once a year, batches of 20-25 breeding ewes per breeding pen were joined with a fertile Barki ram for breeding season which lasted for 34 days (two estrous cycles), ram was replaced by another in case of disability. After the termination of the breeding season, ewes were separated from rams and grouped in large yards until lambing.

\section{B. Flock management}

Lambing took place in October-November or February-March according to the timing of breeding season. Soon after Lambing, each lamb was identified by metal 
ear tags and birth weights were recorded. Lambs were weighed biweekly until weaning. Lambs were kept with their dams during the suckling period until weaning which took place at an average age of 120 days. Ram lambs and ewe lambs selected for replacement were allowed to breed for first time at approximately 18 months of age. Mohammady (2005) gave more details of the management practices of the studied flock.

\section{Feeding regime}

The studied flock was kept under regular feeding regime due to management program and physiological status of the ewes. In summer, sheep were fed on concentrates $(0.25 \mathrm{~kg} / \mathrm{head} /$ day), wheat or barley straw and berseem hay (Trifolium alexandrinum) ad lib. While in winter, sheep were fed on berseem plus straw. Whenever available, the flock was allowed to graze in neighboring areas from sunrise till sunset. Flushing took place two weeks before breeding season and during late pregnancy and early lactation. During these periods ewes were offered with formula concentrate mixture feeds at the rate of $0.5-1 \mathrm{~kg} / \mathrm{head} /$ day according to their physiological status. Rams used for breeding were given the above mentioned ration plus an extra $0.25 \mathrm{Kg}$ of barley/head/day during the breeding season. Fresh water was available for the flock twice a day.

\section{Statistical Analysis}

Least squares analysis described by SAS (1998) was performed using a fixed effect linear model for all studied traits and to develop technical coefficients of the two simulated flocks. The non-genetic factors included in the model thought to exert effects on the studied traits were age of dam, breeding season (summer or autumn) and year of breeding. As the data allowed, interactions between these factors were also considered. The fixed linear model used to analyze the biological traits was as follows:

$\mathrm{Y}_{\mathrm{ijk}}=\mu+\mathrm{a}_{\mathrm{i}}+\mathrm{b}_{\mathrm{j}}+\mathrm{c}_{\mathrm{k}}+(\mathrm{ab})_{\mathrm{ij}}+\mathrm{e}_{\mathrm{ijk}}$

Where:

$\mathrm{Y}_{\mathrm{ijk}}=$ the observations,

$\mu=$ the overall mean,

$\mathrm{a}_{\mathrm{i}}=$ the effect due to $\mathrm{i}^{\text {th }}$ age of dam, $\mathrm{I}=2$ to 10 years,

$b_{j}=$ the effect due to $j^{\text {th }}$ breeding season, $j=1$ and 2 for summer and autumn breeding season, respectively,

$\mathrm{c}_{\mathrm{k}}=$ the effect due to $\mathrm{k}^{\text {th }}$ year of breeding, $\mathrm{k}=1$ to 33 ,

$(\mathrm{ab})_{\mathrm{ij}}=$ the interaction between age of dam and breeding season,

$\mathrm{e}_{\mathrm{ijk}}=$ the error. This element represents all the unidentified factors that may affect the trait under investigation and are not included in the model.

\section{Simulated Flocks}

Barnard and Nix (1993) reported that simulation methods can be used to study the effect of changes in different management practices of the flock. Moreover, Ronald (1981) reported that the farm manager must select from among the many alternatives that will help managers maximize profit. Deterministic technical coefficients derived from least squares analysis of the basic data were used to create two simulated flocks, varying in breeding season, in order to investigate the impact of the biological performance of the two studied breeding seasons (summer or autumn) on the farm 
profitability. In order to compare the two simulated flocks, and to estimate the economic consequences of changing time of breeding season, the following general assumptions were used:

- Flock size is 500 breeding ewes of local Barki sheep for each flock.

- Flock is raised under semi-intensive production system.

- Management of the two simulated flocks was supposed to be similar to the standard practices used in the original flock.

- Weaning age at 4 months.

- Annual culling rate of the breeding ewes $=15 \%$.

- Annual ewe mortality $=2 \%$.

- Annual replacement rate in the breeding flock $=17 \%$.

- Annual manure production $=1 \mathrm{~m}^{3} /$ per ewe.

- Annual veterinary care under both flocks $=20 \mathrm{LE} /$ per ewe.

- Greasy fleece weight $=1.5 \mathrm{Kg} /$ per ewe.

- Actual farm-gate prices in Egyptian Pound (LE) prevailing in 2007 were used.

\section{Economical Analysis}

Economical analyses were undertaken to compare the profitability of the two simulated flocks. Budgeting analysis is a powerful approach used to select the most profitable farm plan among a number of alternatives and to test the profitability of any proposed change in management system.

Annual gross margins (per flock and per ewe), marginal rate of return (MRR) which measures the increase in revenues that is generated by each additional unit of variable cost as well as, benefit/cost ratio $(\mathrm{B} / \mathrm{C})$ and cost of $1 \mathrm{~kg}$ of meat produced were used to indicate the relative profitability of the two simulated flocks.

\section{RESULTS AND DISCUSSION}

\section{A. Biological Performance}

Results of least squares procedure are presented in Table (1). The overall least squares means for EL/EJ, LB/EJ, LW/EJ and $\mathrm{KGW} / \mathrm{EJ}$ were $78 \%, 80 \%, 61 \%$ and $11.9 \mathrm{~kg}$, respectively. The least squares estimate for EL/EJ obtained in the present study is close to that reported by Mabrouk (1970) of $79.2 \%$ and Mohammady (2005) of $79 \%$ for the same breed, but lower than those given by Salem (1990) of $87 \%$ and Mohammady (1999) of $82.4 \%$. The differences in estimates reported by different authors might be attributed to the differences in management practices and environmental conditions.

Autumn breeding season had significantly $(\mathrm{P}<0.05)$ higher estimate of EL/EJ than summer breeding season (79\% vs. $76 \%$ ). This result is in agreement with that cited by Aboul-Naga and Aboul-Ela (1987), Aboul-Naga et al. (1992), Morsy (2002) and Mohammady (2005). The differences between both seasons may be attributed to the frequency of estrus cycle and conception rate. In this context, Aboul-Naga et al. (1992) cited that conception rate in Egyptian sheep rises to maximum in September (autumn breeding season). There is good evidence that changes in daylight are a major factor causing changes in oestrus activity in subtropical sheep (Aboul-Naga et al., 1987). It is recommended that feeding conditions must be improved during autumn season which may be considered as a natural flushing. 
All factors and interaction included in the model, had a significant $(\mathrm{P}<0.05)$ effect on this trait except year of breeding had highly significant $(\mathrm{P}<0.01)$ effect. The finding that year exerted substantial effect, reflects year to year variation in environmental conditions, in particularly nutritional ones.

Table 1. Least squares means $(\bar{X})$ and standard error (SE) for different traits of the studied flock

\begin{tabular}{|c|c|c|c|c|c|}
\hline \multirow[t]{2}{*}{ Classification } & \multirow[t]{2}{*}{ No. } & EL/EJ(\%) & LB/EJ (\%) & LW/EJ(\%) & KGW/EJ \\
\hline & & $\bar{X} \pm \mathbf{S E}$ & $\bar{X} \pm \mathbf{S E}$ & $\bar{X} \pm \mathbf{S E}$ & $\bar{X} \pm \mathbf{S E}$ \\
\hline Overall mean & 6483 & $78 \pm 0.49$ & $80 \pm 0.50$ & $61 \pm 0.60$ & $11.9 \pm 0.128$ \\
\hline Age of ewe & & $*$ & $* *$ & $* *$ & $* *$ \\
\hline 2 & 1573 & $78 \mathrm{ab} \pm 1.00$ & $80 \mathrm{abc} \pm 1.10$ & $60 \mathrm{a} \pm 1.30$ & $11.4 b \pm 0.260$ \\
\hline 3 & 1336 & $77 \mathrm{ab} \pm 1.10$ & $79 \mathrm{abc} \pm 1.20$ & $62 \mathrm{a} \pm 1.40$ & $11.9 \mathrm{ab} \pm 0.282$ \\
\hline 4 & 1101 & $80 \mathrm{ab} \pm 1.20$ & $84 a b c \pm 1.30$ & $66 \mathrm{a} \pm 1.50$ & $13.4 a \pm 0.310$ \\
\hline 5 & 896 & $74 a b \pm 1.30$ & $78 \mathrm{c} \pm 1.50$ & $63 a \pm 1.70$ & $12.7 \mathrm{ab} \pm 0.344$ \\
\hline 6 & 604 & $75 \mathrm{ab} \pm 1.60$ & $78 b c \pm 1.80$ & $61 \mathrm{a} \pm 2.00$ & $11.9 \mathrm{ab} \pm 0.419$ \\
\hline 7 & 409 & $81 \mathrm{a} \pm 1.90$ & $86 a \pm 2.20$ & $64 \mathrm{a} \pm 2.50$ & $12.3 \mathrm{ab} \pm 0.509$ \\
\hline 8 & 258 & $78 \mathrm{ab} \pm 2.40$ & $84 a b c \pm 2.70$ & $66 \mathrm{a} \pm 3.10$ & $12.8 \mathrm{ab} \pm 0.641$ \\
\hline 9 & 155 & $77 \mathrm{ab} \pm 3.20$ & $85 \mathrm{ab} \pm 3.50$ & $63 a \pm 4.00$ & $11.5 b \pm 0.827$ \\
\hline 10 & 151 & $74 \mathrm{~b} \pm 3.20$ & $79 \mathrm{abc} \quad 3.60$ & $50 \mathrm{~b} \pm 4.00$ & $8.9 c \pm 0.838$ \\
\hline $\begin{array}{l}\text { Breeding } \\
\text { season }\end{array}$ & & $*$ & $*$ & $*$ & $*$ \\
\hline Summer & 2749 & $76 b \pm 0.70$ & $78 b \pm 0.80$ & $55 \mathrm{~b} \pm 0.90$ & $10.3 b \pm 0.196$ \\
\hline Autumn & 3734 & $79 a \pm 0.60$ & $83 a \pm 0.70$ & $67 a \pm 0.80$ & $13.4 \mathrm{a} \pm 0.168$ \\
\hline Year & & $* *$ & $* *$ & $* *$ & $* *$ \\
\hline Age $\mathrm{x}$ season & & $*$ & $* *$ & $*$ & $*$ \\
\hline
\end{tabular}

Annual crop of lambs born per ewe joined (LB/EJ) is of interest to ensure replacement, provide surplus stock either for sale or build up numbers and to ensure as high selection differential as possible (Turner et al., 1968). The overall mean of $\mathrm{LB} / \mathrm{EJ}$ is $80.4 \%$. This estimate is higher than those reported for the same breed by Bedier (1987) of $63.0 \%$, Younis et al. (1984) of $79.0 \%$ and $68.0 \%$ under experimental and commercial farms, respectively. Analysis of variance revealed that ewes bred in autumn breeding season had significantly $(\mathrm{P}<0.05)$ higher LB/EJ than those bred in summer season (83\% vs. $78 \%$ ). This result is in accordance with those reported by Aboul-Naga et al. (1991), Mokhtar et al. (1991), Maharem (1996) and Mohammady (2005). The first two authors found that September mating season was characterized by a significant increase in conception and higher incidence of multiple birth over May mating season. Squires (2003) and Vanroose (2003) reported that, reduction of $\mathrm{LB} / \mathrm{EJ}$ in summer breeding season may be due to the increase in prenatal mortality as a result of heat stress during pregnancy in the hot summer months.

Number of lambs weaned per ewe joined (LW/EJ) combines fertility of ewe and ram, prolificacy and survival of lambs. The overall least squares mean of the current 
study is $60.8 \%$. However, the current estimate is higher than those reported by Bedier (1987) of 59\% and Ahmed et al. (1992) of 54\% for the same breed. Seasonal variation was more pronounced that LW/EJ of autumn breeding season exceeded significantly $(\mathrm{P}<0.05)$ that of ewes breeding at summer $(67 \%$ vs. $55 \%)$. This result is in accordance with those reported by Aboul-Naga and Abou-Ela (1987), Nawaz et al. (1998), Mokhtar et al. (1991), Maharem (1996) and Mohammady (2005). This may due to availability of green fodder at lambing season in February and March which might have improved milking ability, in addition to low ambient temperature might inhibit pathogenic factors that cause lambs mortality.

The general mean of KGW/EJ of the current study is nearly the same as that reported by Bedier (1987) of $11.08 \mathrm{~kg}$. However, lower estimates were reported by Younis et al. (1990) and Ahmed et al. (1992). Moreover, analysis of variance indicates that $\mathrm{KGW} / \mathrm{EJ}$ tended to be significant $(\mathrm{P}, 0.05)$ higher in autumn breeding season than summer breeding season $(13.4 \mathrm{~kg}$ vs. $10.3 \mathrm{~kg})$. This parameter is a function of lambing rate, twining rate and lambs mortality. It indicates as well, the mothering ability of ewe and growth rate of lambs in the flock. In addition, the economical performance of sheep farms is finally evaluated on the basis of the total value of lambs crop produced. All factors and interaction included in the model affected this trait significantly.

It could be concluded from biological point of view that, autumn breeding season flock had a higher biological performance than summer breeding season flock in all studied traits.

\section{B. Economical Performance}

Results of economical analysis of the two simulated flocks are shown in Table (2). It is clear that the variation of the attained values of revenues and variable costs reflected the management practices of the flock. When comparing the achieved total gross margin of the two simulated flocks, it was shown that the flock of autumn breeding season generated higher gross margin than that of summer breeding season (LE 47703 vs. LE 30699). The difference represented about $55.0 \%$ in favor of autumn breeding season. Moreover, results showed that total revenues of autumn breeding season flock were higher than the other season by $18.7 \%$ (182875 LE vs. 154085 LE).

Breakdown of the obtained annual revenues revealed that weaned ram lambs are the major source of revenues of the two simulated flocks and it represented $34.6 \%$ and $38.0 \%$ of total annual revenues of summer and autumn breeding season's flocks, respectively. These results declared the great impact of biological performance of the flock on farm revenues.

In this context, annual variable costs figures accounted for some of the increased costs that would be associated with improved reproduction such as increased feed costs due to extra number of ewes lambed. Feeding costs contributed main components of the annual variable costs for both simulated flocks $(74.3 \%$ and $76.6 \%$, respectively). This finding is in agreement with those reported by Galal et al, (1993), where feeding costs were reported to range from $68.7 \%$ to $88.7 \%$ in contribution to total variable costs. Annual variable costs of the autumn breeding season flock recorded higher value than summer breeding season (LE 135172 vs. LE 123186). 
Table 2. Breakdown of the annual revenues and annual variable costs of the two simulated flocks

\begin{tabular}{|c|c|c|c|c|}
\hline \multirow[t]{2}{*}{ Item } & \multicolumn{2}{|c|}{ Summer breeding season } & \multicolumn{2}{|c|}{ Autumn breeding season } \\
\hline & Value (LE) & $\%$ & Value (LE) & $\%$ \\
\hline \multicolumn{5}{|l|}{ Revenues: } \\
\hline Weaned ram lambs & 53323 & 34.6 & 69485 & 38.0 \\
\hline Surplus ewe lambs & 17385 & 11.3 & 30015 & 16.4 \\
\hline Culled ewes & 50625 & 32.8 & 50625 & 27.7 \\
\hline Culled rams & 18000 & 11.7 & 18000 & 9.8 \\
\hline Wool & 2250 & 1.5 & 2250 & 1.2 \\
\hline Manure & 12500 & 8.1 & 12500 & 6.9 \\
\hline Total revenues & 154085 & 100 & 182875 & 100 \\
\hline \multicolumn{5}{|l|}{ Variable costs: } \\
\hline Feeding & 83652 & 74.3 & 89685 & 76.6 \\
\hline Labor & 14400 & 17.5 & 14400 & 16.0 \\
\hline Veterinary care & 10000 & 8.2 & 10000 & 7.4 \\
\hline Total variable costs & 123186 & 100 & 135172 & 100 \\
\hline Total gross margin & 30699 & & 47703 & \\
\hline
\end{tabular}

The attained results revealed the benefits from improving reproductive performance of the flock. Barki sheep are capable of making use of extra feeding costs, and they could transform these inputs into more financial returns, and the extra returns from $\mathrm{KGW} / \mathrm{EJ}$ of autumn breeding season flock covers the additional feeding costs required for feeding the extra number of pregnant ewes.

\section{Economical Indicators}

The effects of management practices changes (summer breeding season vs. autumn breeding season) on biological performance and economical efficiency of the two studied simulated flocks are shown in Table (3). The obtained results declared obviously the economic consequences of the biological performance of the flock. Poor biological performance (summer breeding season) reduced returns and profitability through its effects on several areas of flock performance. Poor estimates of EL/EJ, LB/EJ, LW/EJ and $\mathrm{KGW} / \mathrm{EJ}$ resulted in fewer number of ewe lambs for replacement and surplus for sale, less quantity of meat produced in addition to limited culling and slower rate of genetic progress.

Applying autumn breeding season improved annual returns per ewe and gross margin per ewe by LE 57.6 and LE 33.7, respectively. Moreover, benefit/cost ratio increased from 1.25 for each unit of money spent to 1.35 . In the same time, results also revealed that both revenues and variable cost per ewe increased. In spite of the annual variable cost per ewe in the autumn breeding season flock increasing by LE 23.9 , it is of interest to notice that marginal rate of return achieved 2.4 , which means that, each additional unit of variable cost increased revenues of the flock by LE 2.4.

The objective of sheep producers is to maximize the difference between what it costs to produce a $\mathrm{kg}$ of meat and what price received. The obtained indicators clarify that, cost of one kg of meat produced under autumn breeding season flock is less than summer breeding season flock by LE 1.17. 
Table 3. The effect of changes in management practices on biological performance and economical efficiency of the two simulated flock. (LE)

\begin{tabular}{lcc}
\hline Indicator & $\begin{array}{c}\text { Summer breeding } \\
\text { season }\end{array}$ & $\begin{array}{c}\text { Autumn breeding } \\
\text { season }\end{array}$ \\
\hline Biological performance: & 0.757 & 0.788 \\
$\quad$ EL/EJ & 0.775 & 0.825 \\
LB/EJ & 0.551 & 0.673 \\
LW/EJ & 10.3 & 13.4 \\
KGW/EJ & & \\
Economical indicators: & 308.2 & 365.8 \\
Annual returns per ewe & 246.4 & 270.3 \\
Annual cost per ewe & 61.8 & 95.5 \\
Gross margin/ewe & ---- & 2.40 \\
Marginal rate of return & 15.77 & 14.60 \\
Cost of 1 kg of meat produced & 1.25 & 1.35 \\
Benefit/cost ratio & & \\
\hline EL/EJ, \% of ewes lambing per ewe joined: LB/EJ, \% of lambs born per ewe joined; LW/EJ, \% \\
of lambs weaned per ewe joined; KGW/EJ, Kilograms weaned per ewe joined.
\end{tabular}

\section{CONCLUSION}

All evidence estimated in the current study suggests that maintaining a high level of biological performance is required to improve flock profitability. It could be concluded that, the cost of improving reproductive management is not likely to be high enough under any circumstances to make improving reproductive performance an unprofitable activity. The obtained results in this study indicate that there is considerable scope for sheep producers to improve economical efficiency of their current sheep flock by refining their time of breeding.

\section{REFERENCES}

Aboul-Naga, A.M., 1985. Crossbreeding for fecundity in subtropical sheep. Pp. 5562. In: R. Land and D. Robinson, Eds., Genetics of reproduction in sheep, Butterworths, London.

Aboul-Naga, A.M. and M.B. Aboul-Ela, 1987. Performance of subtropical Egyptian sheep breeds, European breeds and their crosses 1. Egyptian sheep breeds. World Review of Anim. Prod., 23:75-82.

Aboul-Naga, A.M., M.B. Aboul-Ela and H. Mansour, 1991. Seasonality of breeding activity in subtropical Egyptian sheep breeds. $38^{\text {th }}$ Annual Meeting of EAAP, Lisbon, Portugal.

Aboul-Naga, A.M., M.B. Aboul-Ela and F. Hassan, 1992. Manipulation of reproductive activity in subtropical sheep. Small Ruminant Research, 7:151-160.

Aboul-Naga, A.M., M.B. Aboul-Ela, H. Mansour and H. Almahdy, 1991. Breeding activity in two subtropical Egyptian sheep breeds under accelerated lambing system. Small Ruminants Research, 4: $285-292$.

Ahmed, A.M., E.S.E. Galal and A.A. Younis, 1992. Estimates of productive and reproductive performances of commercial flock of Barki sheep. Egyptian J. Anim. Prod., 29:109-122. 
Barnard, C.S. and J.S. Nix, 1993. Farm Planning and Control, $2^{\text {nd }}$ Edition. Cambridge University Press, Cambridge.

Bedier, N.Z., 1987. A study on optimum ewe size under desert conditions. Ph.D. Thesis. Faculty of Agriculture, Ain-Shams University, Cairo.

El-Fouly, M., M. Shafie, A. Abdel-Aziz and S. Kandeel, 1977. Seasonal variation in oestrous activity in Ossimi and Rahmani ewes. Egyptian J. Anim. Prod., 17: 75.

Fahmy, M.H., E.S.E. Galal, Y.S. Ghanem and S.S. Khishin, 1969. Crossbreeding of sheep under semi-arid conditions. Anim. Prod. 11: 351.

Galal, E.S.E., A.M. Ahmed, A.I. Abdel-Aziz and A.A., Younis, 1993. Effect of increasing lambing frequency and crossbreeding on performance of sheep production systems in semi-arid environments. Small Ruminant Research, 10:143-152.

Mabrouk, M.M., 1970. Studies on the reproductive performance of sheep under coastal desert conditions. M.Sc. Thesis, Al-Azhar University, Cairo, Egypt.

Maharem, O.M.A., 1996. The productive performance of Awassi, Barki sheep and their crosses under Egyptian North West Coastal environment. Ph.D. Thesis, Alexandria University, Egypt.

Mohammady, M.I., 1999. Biological efficiency of sheep and goat production. M.Sc. Thesis, Faculty of Agriculture, Cairo University.

Mohammady, M.I., 2005. Flock dynamics of desert Barki sheep in relation to age structure. Ph.D. Thesis, Faculty of Agriculture, Cairo University.

Mokhtar, M.M., H.T. Abdel-Bary, A.A. Younis, M.S. Mabrouk and H. Abdel-Aziz, 1991. Comparative study of two systems of production in Barki sheep. Egyptian J. Anim. Prod., 28:21-30.

Morsy, A.H., 2002. Evolution of prolific and non-prolific breeds of sheep under the environmental conditions of Middle Egypt. Ph.D. Thesis, Mania University.

Nawaz, M., M.A. Khan, M.A. Qureshi and E. Rasool, 1998. Productive and reproductive performance of Kajli and Lohi ewes. Asian Aust. J. Anim. Sci. 12:1, 61-67.

Ronald, D.K., 1981. Farm Management. McGraw-Hill Book Company, New York.

Salem, H.A., 1990. A study on the frequency of lambing in relation to productivity in Barki sheep. M.Sc. Thesis, Faculty of Agriculture, Al-Azhar University, Cairo, Egypt.

SAS, 1998. User's guide, 6.03 Edition, Statistical Analysis System Institute Inc. Cary NC 27511-8000, USA.

Squires, E.J., 2003. Applied Animal Endocrinology. CABI Publishing, Canada.

Turner, H.N., G.H. Brown, and G.H. Ford, 1968. The influence of age structure on total productivity in breeding flock of Merino sheep. 1. Flocks with a fixed number of breeding ewes, producing their own replacement. Aust. J. Agric. Res., 19: 443-745.

Vanroose, G., A. de Kruif, A. Van Soom, 2003. Embryonic mortality and embryopathogen interactions. Anim. Reprod. Sci., 60-61: 131-143.

Younis, A.A., M.M. Abdel-Aziz, E.A. Afifi, and M. Khaiery, 1984. Biological efficiency of meat production in Barki sheep. World Rev. of Anim. Prod. XX, (4)32.

Younis, A.A., E.S.E., Galal, N.Z., Bedier, Y.S. Ghanem, and K., Ghonem, 1990. Reproductive performance and lamb production of purebred and crossbred sheep. World Rev. of Anim. Prod., 2: 87-92. 


\section{التقييم الحيوي للأغنام البرقي تحت موسمين مختلفين للتربية}

على مصطفى أحمد

مركز بحوث الصحراء- شعبة الإنتاج الحيوانسي ـ المطرية ـ القاهرة

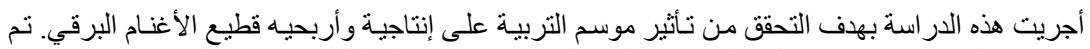

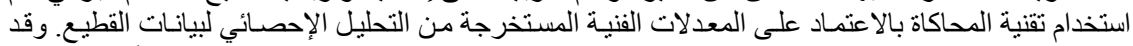

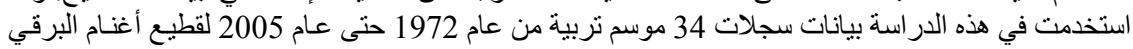

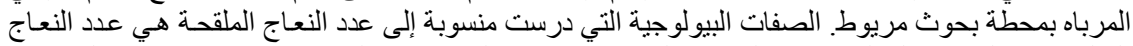

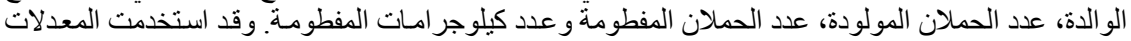

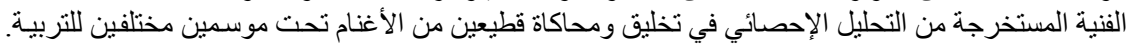

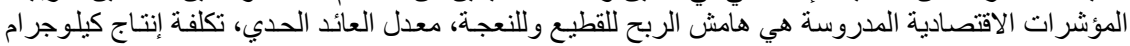

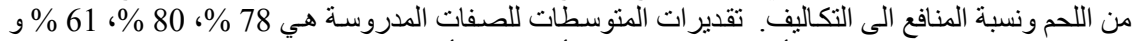

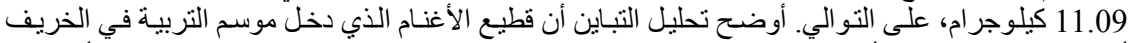

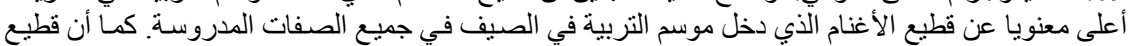

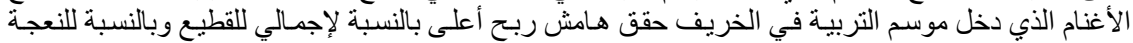

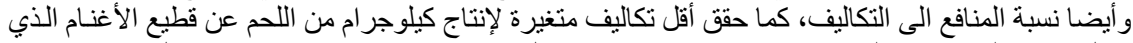

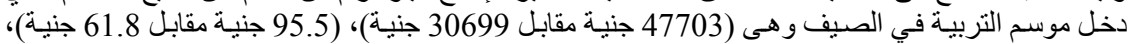
(1.35 مقابل 1.25) و (14.6 جنية مقابل 15.8 جنية)، على التو الي. بينما حقق معدل العائد الحدي 2.4 جنية. 